\title{
Introduction: Artists' Books and Medical Humanities
}

\section{Stella Bolaki ${ }^{1}$}

Published online: 5 December 2019

(C) Springer Science+Business Media, LLC, part of Springer Nature 2019

This special issue developed from the research project, "Artists' Books and Medical Humanities," led by the School of English at the University of Kent (UK) and the Maine Women Writers Collection at the University of New England (US). Funded by the Wellcome Trust, the project took place in Canterbury, UK in 2016. It included the exhibition, "Prescriptions: Artists' Books on Wellbeing and Medicine" (Beaney Art Museum, 21 April-25 September 2016) that I curated with book artist and researcher Egidija Čiricaite; an academic symposium, and a series of book making workshops for health professionals, people with illness, and the wider public. Bringing together international contributors who are artists, scholars, educators, and archivists (including contributors who combine one or more of these identities), the special issue seeks to continue the critical conversations opened by the above activities and to advance models of interdisciplinarity and collaboration that invigorate the fields of both artists' books and the medical humanities.

Emerging in the twentieth century as a form of "intermedia" (Higgins 1984) that combines text, image, and various methods of production, the artist's book is an innovative genre. Its identity is continually developing - as distinct from any of its contributing artistic antecedents (for example, sculpture, painting, printmaking, photography) - and remains vital in the digital age (Drucker 2004). While drawing on the book's broader cultural functions, the artist's book extends its conventional conceptions. It integrates its themes with its formal means of realization and engages readers physically through its tactility and materiality. Created for one-on-one interaction and to be 'performed' through handling, artists' books are intimate and "uniquely accessible" as opposed to the untouchable painting hanging on a gallery wall (Klima 1998, 16). Even though an artist's book has to have some reason to be a book, there are few limits and rules as to how it can be constructed.

While their history and scope as an artistic activity continues to be explored (Bodman and Sowden 2010), artists' books are commonly approached as part of a cultural revolution that started in the 1960s. They have functioned "as alternative spaces" (Linker 1980) to the art gallery and within the community of alternative, often communal, spaces that encourage politicized, experimental, and critical art. Despite continuing debate on whether the medium's portability, durability, and inexpensive nature necessarily translate into wide accessibility

Stella Bolaki

S.Bolaki@kent.ac.uk 
(Lyons 1985), the artist's book is viewed as "fundamentally democratic as it imagines every reader as a potential contributor to the dialogue it engages" and "mirrors values to social groups still groping for an identity and a sense of collective purpose" (Wallis 1998, 101).

The arts have become increasingly important for the medical humanities since its establishment as a field of study and not only as vehicles of humanizing medicine or educating health professionals. There is more and more recognition, especially within the second 'wave' of the medical humanities, of the democratizing and radical contribution of the arts: their potential to generate alternative knowledges of the body and new methodologies for exploring questions of health and illness and to foster critical pedagogies that challenge authoritarian hierarchies and encourage tolerance of ambiguity within the culture of medicine (Macneill 2011; Bleakley 2015; Whitehead and Woods 2017). Even though the artist's book has affinities with other less utilitarian and subversive art forms such as comics and performance art, it has not been explored systematically within the medical humanities and arts in health fields. Complementing work in the burgeoning area of 'graphic medicine,' this special issue redresses the gap in scholarship and practice on multimodal forms and mixed-arts practices within medical humanities and healthcare education.

All contributors to this special issue highlight the versatility and communicative power of the artist's book. The essays discuss the book as narrative, visual form, performance and physical object, and focus on hand-made, digitally printed, and electronic books that adopt different constructions and formats. Several common threads and synergies emerge. The book as a form and idea has rich cultural and metaphorical associations including with the body. Dominant metaphors such as the 'body as machine' perpetuate the dehumanizing and objectifying aspects of medical care. As the essays demonstrate, artists' books can defamiliarize habitual modes of perception by opening up traditional ideas of the body within medicine. They can help reignite a sense of "wonder" and mystery when it comes to confronting our bodies' materiality (Evans 2016) and "re-enchant" medical experience as they invest in alternative images that fall outside strictly clinical frameworks (Willis et al. 2013, 67). For example, Amanda Couch's books embody the process of digestion through different book formats and by drawing connections to handwriting, reading, as well as the ancient science of extispicy (divination using the entrails). Similarly, Véronique Chance's stop-frame animation/ artist's book, In the Absence of Running, disperses the medical gaze through the artistic resignification of her knee arthroscopies. Removed from its original context of technically advanced medical visualisation, the oversized image she creates by putting together her knee scans taken during surgery becomes, as she describes it in her essay, "a time-sequence of planets or moons, an abstract painting or a stained-glass window." Chance's series of artworks that reflect on different modes of viewing and experiencing images - medical and artistic, including the connection between physical and electronic book forms - were inspired by her lived experience of not being able to run due to chronic injury. Her running art-practice that forms part of a larger inquiry into the performative nature of human physical activity restores the "sensual, experiential and creative aspects" that are often marginalized when running is reduced to a tool, pursued for merely practical health reasons. Similarly, the body experiencing loss of consciousness becomes associated with stories of enchanted sleep, magical languages, and shaman healers in Julie Brixey-Williams's Rosebud. Despite being able to recognize Rosebud's flow loop forms, the anesthetists, with whom the artist collaborated to make this work, were "still required to enter the fairy tale and use their imagination to make sense of [its] elusive calligraphy." Interacting with this book turned them into "storytellers." 
All essays emphasize the importance of intimate, palpable, multisensory knowledge that artists' books offer in areas such as illness communication, pedagogy, and public health. Reading artists' books translates into an embodied and often meditative practice that requires an active reader. Contributors examine the 'authority' that derives from certain aesthetic responses to illness experience, and how as multimodal forms artists' books are able to capture complex experiences that resist narrative forms of representation (Stella Bolaki). Essays also draw attention to the unique, deep, and powerful ways of understanding patient experience that artists' books cultivate for medical students, and to the intimate dialogue they foster to encourage empathy (Jennifer Tuttle and Cathleen Miller). Couch's and Bolaki's discussion of the connections between reflection, digestion, and book arts practices further reveals this medium's contribution to a medical education and pedagogy that engages both body and mind, while Brixey-Williams illustrates its potential to make visible the hidden or intangible elements of the anesthetist's working life, of which the public is often unaware. Like Tuttle and Miller, whose essay provides a model for how artefacts and archives might be used at other educational institutions, Brixey-Williams showcases the value of creative experimentation and collaboration in book art practices and the medical/health humanities beyond this particular art residency.

"What am I experiencing when I turn these pages? This is what the critic of an artist's book must ask," and, as Dick Higgins adds, "for most critics it is an uncomfortable question" (1985, 12). This is because "the language of normative criticism is not geared towards the discussion of an experience, which is the main focus of most artists' books" (Ibid, 12). In an attempt to offer readers the experience of 'turning' the pages, as much as this is possible when the book cannot be handled, in addition to the above essays that offer analyses of artists' books, the special issue photographically reproduces excerpts from five books that are part of the 'Prescriptions: Artists' Books' Collection, courtesy of Special Collections and Archives at the University of Kent. These books use different structures and formats to explore themes connected to health, illness, and medicine and have links to the topics treated in the essays.

Inside (2013) by Yvonne J. Foster is a digitally printed pamphlet which documents the experience of living with depression through its altered photographs and scribbled images. Direct and "unapologetic," it challenges the stigma towards mental health. Anne Parfitt's Diary of an Illness (2000-1) captures the acute sensitivity to each minute, hour, and day that is typical of a patient's experience of waiting for diagnosis and treatment. Devising a personal metaphor for time, this concertina book consists of repeated sequential drawings of a black ornamental bottle; each drawing is "an imitation of the previous, yet never identical ... mirroring the indistinguishable yet unique nature of each moment." Other artists record interactions with health professionals in a humorous way. Mary Rouncefield's watercolour and ink book, Mr Darcy's Advice to the Hip Patient (2013), offers a playful take on "rules designed to help patients avoid dislocating their replacement hips" during the artist's recovery from a hip operation. With a touch of humour, Humpty Dumpty's Bones (2014) by Bernard Fairhurst intersperses MRI images from 38 years of spinal problems with comments from health professionals in his auto-ethnographic account of chronic illness, presented through ring binding and typewritten text to emphasize the impersonality of medical discourse. Finally, Dependency (2016) by Pauline Lamont-Fisher uses the concertina format to chart the progress of Alzheimer's disease. The book begins with an image of a baby boy who is looked after his father and closes with the same image but with the roles of carer and cared reversed this time. These two images are connected by lines made of thread; straight lines, progressively initially subtly and then chaotically - become tangled up as readers navigate the book's pages. 
This is a visual analogy to the cognitive deterioration associated with the disease as well as a metaphor for the brain plaques and tangles that can be seen forming on the reverse side of the book.

Even though the photographs cannot offer readers the tactile and sensuous pleasure of handling the actual books - Egidija Čiricaitè who photographed them offers some thoughtful reflections on the challenges of reproducing artists' books in this way - it will hopefully inspire those who are encountering artists' books for the first time to engage with this dynamic art form in the future. I am honored that the special issue concludes with an insightful and stirring response by Johanna Drucker. She is a visual theorist and book artist who has been a passionate advocate of the artist's book and whose commitment to this subject has made it possible to welcome researchers from distant disciplines, such as the medical humanities, to the cause of artists' books.

Acknowledgements The guest editor would like to acknowledge the support of the British Academy (BA/ Leverhulme Small Research Grant 2016-17) in conducting further research for this journal special issue.

\section{Endnotes}

${ }^{1}$ See Bates, Bleakley and Goodman 2014 who concentrate on the discrete categories of visual, performing and literary arts in relation to medical humanities; and Osman, Eacott and Willson 2017 whose analysis of arts-based interventions within healthcare education indicates a small percentage of mixed-arts interventions in comparison to the above categories.

${ }^{2}$ All descriptions of the books below draw on the artists' statements that were used in the Prescriptions exhibition and the subsequent catalogue (see Bolaki and Čiricaite 2017).

\section{References}

Bates, Victoria, Alan Bleakley and Sam Goodman, eds. 2014. Medicine, Health and the Arts: Approaches to the Medical Humanities. London: Routledge.

Bleakley, Alan. 2015. Medical Humanities and Medical Education: How the Medical Humanities Can Shape Better Doctors. London: Routledge.

Bodman Sarah and Tom Sowden. 2010. A Manifesto for the Book. "What will be the canon for the artist's book in the 21st Century?" Accessed 28 May 2018. http://www.bookarts.uwe.ac.uk/canon/.

Bolaki, Stella and Egidija Čiricaitè, eds. 2017. Prescriptions: Artists' Books on Wellbeing and Medicine. London: Natrix Natrix Press.

Drucker, Johanna. 2004. The Century of Artists' Books. New York: Granary Books.

Evans, Martyn. 2016. "Medical Humanities and the Place of Wonder." In The Edinburgh Companion to the Critical Medical Humanities, edited by Anne Whitehead and Angela Woods, 339-355. Edinburgh: Edinburgh University Press.

Higgins, Dick. 1984. Horizons: The Poetics and Theory of the Intermedia. Carbondale, IL: Southern Illinois University Press.

- 1985. “A Preface.” In Artists' Books: A Critical Anthology and Sourcebook, edited by Joan Lyons, 11-12. Rochester, N.Y.: Visual Studies Workshop Press.

Klima, Stefan. 1998. Artists' Books: A Critical Survey of the Literature. New York: Granary Books.

Linker, Kate. 1980. “The Artist's Book as an Alternative Space.” Studio International 195:75-79.

Lyons, Joan, ed. 1985. Artists' Books: A Critical Anthology and Sourcebook. New York: Visual Studies Workshop Press.

Macneill, Paul Ulhas. 2011. "The Arts and Medicine: A Challenging Relationship.” Medical Humanities 37:8590. 
Osman, Magda, Bella Eacott and Suzy Willson. 2017. "Arts-based Interventions in Healthcare Education." Medical Humanities 44:28-33.

Wallis, Brian. 1998. "The Artist's Book and Postmodernism.” In Artist/Author: Contemporary Artists' Books, edited by Cornelia Lauf and Clive Phillpot, 93-101. New York: The American Federation of Arts.

Willis, Martin, Waddington Keir and Marsden Richard. 2013. "Imaginary Investments: Illness Narratives Beyond the Gaze." Journal of Literature and Science 6 (1): 55-73.

Whitehead, Anne and Angela Woods, eds. 2017. The Edinburgh Companion to the Critical Medical Humanities. Edinburgh: Edinburgh University Press.

Publisher's Note Springer Nature remains neutral with regard to jurisdictional claims in published maps and institutional affiliations. 